\title{
Cooking quality, nutritional composition and consumer acceptance of functional jackfruit pasta enriched with red amaranthus
}

\author{
Swathi, B.S. ${ }^{1}$, Lekshmi, G.P.R ${ }^{2}$ and Sajeev, M.S. ${ }^{3}$ 函
}

Received: 01.04.2019

Revised: 20.06.2019

Accepted: 10.08.2019

\begin{abstract}
Jackfruit is an important tropical fruit grown extensively in homesteads of Kerala. Even though jackfruit is a pack house of nutritional components, it remains underexploited and facing huge postharvest loss. Jackfruit bulb and seed are rich in carbohydrates, proteins, fibre and other bioactive compounds and can be utilised for the development of value added products with health benefits and jackfruit pasta is promising as demand for nutritious pasta is increasing domestically as well as internationally. The present study aimed to develop red amaranthus enriched functional jackfruit pasta with natural red colour, nutritional qualities and consumer acceptability. The red amaranthus paste was added in two different proportions (5\% and $10 \%)$ to different formulations of jackfruit pasta comprising of jackfruit bulb flour, seed flour and cassava flour replacing a portion of refined flour. The enrichment with $10 \%$ of red amaranthus as paste to jackfruit pasta formulations reduced cooking loss, improved the cooking quality characters, nutritional quality, and sensory attributes and produced naturally coloured pasta with higher consumer acceptability.
\end{abstract}

Key Words: Amaranthus, Cooking quality, Cooking loss, Functional Pasta, Jackfruit, Swelling index

\section{Introduction}

Jackfruit (Artocarpus heterophyllus Lam.), the largest fruit commonly grown in homesteads of Kerala, is rich in nutrients with enormous health benefits. But the fruit is still considered as underutilized and the high productivity often leads to huge postharvest loss. Jackfruit is not considered as a commercial fruit crop due to its lower shelf life and inadequate postharvest handling facilities in the regions they are grown (Ranasinghe et al., 2019). The fruit is rich in carbohydrates, dietary fibre, proteins, vitamins, minerals and many classes of bioactive phytochemicals viz., polyphenols, carotenoids, flavanoids, volatile compounds which are known to have beneficial effects in healthy diet to prevent degenerative diseases (Chandrika et al., 2004, Arung et al., 2007, and Amit and Ambarish 2010). Pasta is traditionally an Italian food, an excellent source of complex carbohydrates, which provide a slow release of energy made of refined wheat flour which has crossed international borders. Convenience and palatability make pasta Author's Address

1\&2 Department of Post harvest technology, College of Agriculture Vellayani, Thiruvananthapuram, Kerala Agricultural University

3 Division of crop Utilisation, ICAR-CTCRI, Sreekaryam, Thiruvananthapuram.

E-mail.: ms_sajeev@rediffmail.com more popular among the common man in India too (Gull et al., 2015). The demand for pasta enriched with functional ingredients and nutrients increased with increase in income, change in life style, and increased concern towards safe and nutrient rich foods which led to the development of pasta enriched with cereal bran, vegetable puree, fruits, minor cereals and pseudo cereals for people suffering from celiac disease (Meena et al., 2019). As jackfruit bulb and seed contain starch, protein, fibre, calcium, and other bioactive compounds, it can be used for the preparation of healthy pasta. Red amaranthus (Amaranthus tricolor L.) is one of the largely consumed leafy vegetables of Kerala and is well known for its high nutritional quality. It is called as 'poor man's spinach' which is less expensive and easily available source of protective nutrients. Nowadays there is a growing demand for wholesome, nutritional, and convenience food products. Pastas enriched with plant derived bioactive compounds may confer additional health benefits to consumers. Hence the present study was conducted with the objective to develop amaranthus incorporated jackfruit based pasta by adding red amaranthus leaves to make functional pasta with consumer acceptability. 


\section{Materials and Method}

Raw Materials

Fully matured varikka jackfruit (90-110 days after fruit set) of good quality were taken for the study. The bulbs and seeds were separated, blanched, dried and powdered to get jackfruit bulb flour and seed flour. Cassava tubers harvested were cleaned, outer and inner skin removed, washed and grated using 'Tapioca french fry cutter'. The grated cassava was sun dried and pulverized into fine powder in cassava grinding machine. Red amaranthus (Amaranthus tricolor L.) variety Arun of good quality was procured form the field of progressive farmers.

\section{Pasta preparation}

Jackfruit pasta was developed with jackfruit bulb flour and seed flour along with cassava flour replacing a portion of refined flour contributing to $65 \%$ of total ingredients. The remaining $35 \%$ of total ingredients was kept as constant with refined wheat flour, soy flour and cassava starch procured from supermarket. To the jackfruit pasta combinations, red amaranthus leaves and tender stem in paste form was added at 5 and $10 \%$ to the pasta dough for the development of amaranthus incorporated jackfruit pasta. The treatment combinations are

$\mathrm{F}_{1}$ - Jackfruit bulb flour $(20 \%)+$ Jackfruit seed flour $(20 \%)+$ cassava flour $(25 \%)$

$\mathrm{F}_{2}$ - Jackfruit bulb flour $(25 \%)+$ Jackfruit seed flour $(25 \%)+$ cassava flour $(15 \%)$

$\mathrm{F}_{3}-$ Jackfruit bulb flour $(10 \%)+$ Jackfruit seed flour $(30 \%)+$ cassava flour $(25 \%)$

$\mathrm{F}_{4}-\mathrm{F}_{1}+5 \%$ amaranthus

$\mathrm{F}_{5}-\mathrm{F}_{1}+10 \%$ amaranthus

$\mathrm{F}_{6}-\mathrm{F}_{2}+5 \%$ amaranthus

$\mathrm{F}_{7}-\mathrm{F}_{2}+10 \%$ amaranthus

$\mathrm{F}_{8}-\mathrm{F}_{3}+5 \%$ amaranthus

$\mathrm{F}_{9}-\mathrm{F}_{3}+10 \%$ amaranthus

The kneaded pasta dough was extruded using single screw extruder La Monferrina s.r.l. Costell'Alfero (AT) Italy with die for tubular pasta and cut into 2.5 $\mathrm{cm}$ length. The pasta were dried at $50^{\circ} \mathrm{C}$ in hot air oven (Kemi Hot Air Oven, India) till the moisture content reached to 7 to $8 \%$.

\section{Cooking quality of pasta}

Cooking quality of pasta was determined based on cooking loss, water absorption, swelling index and cooking time.

\section{Cooking loss (\%)}

Quantification of cooking loss is important to assess the quality of pasta and was determined by the method of Debbouz and Doetkott (1996) as described by Padmaja (2015). The water drained after cooking is separately dried in pre-weighed petri dishes and kept in an oven at $105^{\circ} \mathrm{C}$ for overnight drying. The weight of the dry residue is quantified $\left(\mathrm{W}_{2} \mathrm{~g}\right)$.

Cooking loss $(\%)=\frac{\mathrm{W}_{2} \times 100}{\mathrm{~W}_{1}}$

where $\mathrm{W}_{1}$ is the initial weight of the pasta.

\section{Water absorption (g g-1)}

Water absorption of pasta was analysed according to Cleary and Brennan (2006). Water absorption is the difference in weight of cooked pasta and uncooked pasta, expressed as the percentage of weight of uncooked pasta. Cooked pasta were rinsed with water and drained, then weighed to determine the gain in weight.

Water absorption $=$ Final weight of cooked pasta - Weight of raw pasta

\section{Swelling index (\%)}

Weight of raw pasta

Swelling index of pasta was determined by the method described by Cleary and Brennan (2006). Approximately $50 \mathrm{~g}$ of the dried pasta (W1) was cooked and the water is drained to a pre-weighed beaker. The cooked pasta is surface dried over a cloth and weight of the cooked pasta $\left(\mathrm{W}_{2}\right)$ is taken.

$$
\text { Swelling index }=\frac{\mathrm{W}_{2}-\mathrm{W}_{1}}{\mathrm{~W}_{1}}
$$

\section{Cooking time (minutes)}

Cooking quality of pasta were analysed according to method of Ojure and Quadri (2012). Ten gram of pasta was cooked in $300 \mathrm{ml}$ of boiling water in a covered beaker. Cooking time was determined by removing a piece of pasta and pressing them between two pieces of glass slides. Optimum cooking was achieved when the centre of pasta became transparent or when the pasta were fully hydrated.

\section{Biochemical analysis}

The biochemical parameters viz., starch, total sugar, reducing sugar, protein, carotenoids, crude fibre, and antioxidant activity were determined for raw as well as cooked pasta. 


\section{Starch (\%)}

The starch content was expressed as per cent in terms of invert sugar according to the following formula (Ranganna, 1986).

$$
\text { Starch }(\%)=\frac{\begin{array}{c}
\text { Glucose Eq. }(0.05) \times \text { Total volume made up }(\mathrm{mL}) \times \\
\text { amount of starch in } 1 \mathrm{~g} \text { solution }(\mathrm{g}) \times 100
\end{array}}{\text { Titre value }(\mathrm{V}) \times \text { Weight of sample taken }(\mathrm{g})}
$$

\section{Total sugar (\%)}

The total sugar content was expressed as per cent in terms of invert sugar according to the following formula (Ranganna, 1986).

$$
\text { Total sugar (\%) }=\frac{\begin{array}{l}
\text { Glucose Eq. (0.05) } \times \text { Total volume made up } \\
(\mathrm{mL}) \times \text { Volume made up after inversion } \\
(\mathrm{mL}) \times 100
\end{array}}{\begin{array}{l}
\text { Titrevalue } \times \text { Weight of sample taken }(\mathrm{g}) \times \\
\text { Aliquot taken for inversion }(\mathrm{mL})
\end{array}}
$$

Reducing sugar (\%)

The titrimetric method of Lane and Eynon as described by Ranganna (1986) was adopted for the estimation of reducing sugar.

Glucose Eq.(0.05) x Total volume made up $(\mathrm{mL}) \quad \mathrm{x}$

Reducing sugar $(\%)=$

Titre value $(\mathrm{mL}) \mathrm{x}$ Weight of the sample $(\mathrm{g})$

\section{Protein (\%)}

Protein content of the pasta was estimated using the method described by Bradford (1976). Amount of protein present in the sample was calculated by plotting a standard curve using the standard protein absorbance against the concentration obtained. From the graph the amount of protein present in the sample can be calculated.

\section{Carotenoids ( $\mu \mathrm{g} 100 \mathrm{~g}^{-1}$ )}

Carotenoids were estimated as per the procedures of Saini et al. (2015) and expressed as $\mu \mathrm{g} 100 \mathrm{~g}^{-1}$ of treated fruit.

\section{Crude fibre (\%)}

Crude fibre content of developed pasta was estimated using the method described by Sadasivam and Manickam (1992). Percentage of crude fibre in the sample was calculated as follows:

$\%$ of Crude fibre $=$ Loss in weight in ignition $\left\{\left(\mathrm{W}_{2}-\mathrm{W}_{1}\right)-\left(\mathrm{W}_{3}-\mathrm{W}_{1}\right)\right\} \times 100$ Weight of the sample

$\mathrm{W}_{1}$ - Weight of crucible

$\mathrm{W}_{2}$ - Weight of crucible and sample after two hours

$\mathrm{W}_{3}$ - Final weight of crucible

\section{Antioxidant activity (\%)}

Total antioxidant activity of developed pasta was determined using 2, 2- diphenyl-1-picrylhydrazyl (DPPH) radical scavenging assay. The scavenging effect on DPPH free radical was measured according to the procedure described by Sharma and Bhat (2009).

Pasta sample $(1 \mathrm{~g})$ was added to $2.0 \mathrm{~mL} 0.1 \mathrm{mM}$ DPPH solution, mixed thoroughly and left for 30 minutes at room temperature. The absorbance was read at $517 \mathrm{~nm}$. Scavenging effect was expressed as percent inhibition of DPPH as shown in the following equation.

$$
\left\{\mathrm{A}_{\text {blank }}-\mathrm{A}_{\text {sample }}\right\} \times 100
$$

$\%$ inhibition of DPPH $=$

Where,

$$
\mathrm{A}_{\text {blank }}
$$

A blank - Absorbance of DPPH solution without sample, read against ethanol blank.

A sample - Absorbance of the test sample after 30 $\min$.

\section{Sensory qualities}

Amaranthus incorporated jackfruit pasta developed by different treatments were evaluated for sensory characteristics viz., appearance, taste, colour, flavour, elasticity, adhesiveness, and overall acceptability by 30 member semi trained panel. The panel was asked to score for the sensory attributes of the samples using 9-point hedonic scale (Ranganna, 1986) in the order of preference as shown below.

Like extremely -9 , Like very much -8 , Like moderately -7 , Like slightly -6 ,

Neither like nor dislike -5, Dislike slightly -4 , Dislike moderately -3

Dislike very much -2, Dislike extremely -1

\section{Statistical analysis}

The data generated from the experiment were statistically analysed using Completely Randomised Design (CRD). The sensory scores were statistically analysed using Kruskall-Wallis test (chi-square value) to find out whether treatments differed significantly (Shamrez et al., 2013)

\section{Results and Discussion}

Pasta developed from different combinations was subjected to analysis for cooking quality, textural, nutritional and sensory parameters. 
Table 1. Evaluation of cooking quality characters of amaranthus incorporated functional

\begin{tabular}{|l|l|l|l|l|}
\hline Treatments & $\begin{array}{l}\text { Cooking } \\
\text { loss }(\mathbf{\%})\end{array}$ & $\begin{array}{l}\text { Water absorption } \\
\left(\mathbf{g ~ g}^{-1}\right)\end{array}$ & $\begin{array}{l}\text { Swelling } \\
\text { index (\%) }\end{array}$ & $\begin{array}{l}\text { Cooking time } \\
\text { (minutes) }\end{array}$ \\
\hline $\mathrm{F}_{1}[\mathrm{JBF}(20 \%)+\mathrm{JSF}(20 \%)+\mathrm{CF}(25 \%)]$ & 16.09 & 1.19 & 1.78 & 6.56 \\
\hline $\mathrm{F}_{2}[\mathrm{JBF}(25 \%)+\mathrm{JSF}(25 \%)+\mathrm{CF}(15 \%)]$ & 16.50 & 1.19 & 2.18 & 6.57 \\
\hline $\mathrm{F}_{3}[\mathrm{JBF}(10 \%)+\mathrm{JSF}(30 \%)+\mathrm{CF}(25 \%)]$ & 18.89 & 1.25 & 2.58 & 6.60 \\
\hline $\mathrm{F}_{4}\left[\mathrm{~F}_{1}+5 \%\right.$ Amaranthus $]$ & 6.84 & 1.03 & 1.06 & 5.23 \\
\hline $\mathrm{F}_{5}\left[\mathrm{~F}_{1}+10 \%\right.$ Amaranthus $]$ & 7.46 & 1.19 & 1.55 & 5.49 \\
\hline $\mathrm{F}_{6}\left[\mathrm{~F}_{2}+5 \%\right.$ Amaranthus $]$ & 7.69 & 1.09 & 1.45 & 6.00 \\
\hline $\mathrm{F}_{7}\left[\mathrm{~F}_{2}+10 \%\right.$ Amaranthus $]$ & 7.81 & 1.34 & 1.66 & 6.12 \\
\hline $\mathrm{F}_{8}\left[\mathrm{~F}_{3}+5 \%\right.$ Amaranthus $]$ & 7.55 & 1.17 & 1.66 & 6.20 \\
\hline $\mathrm{F}_{9}\left[\mathrm{~F}_{3}+10 \%\right.$ Amaranthus $]$ & 8.93 & 1.49 & 2.16 & 6.22 \\
\hline $\mathrm{CD}$ & 2.135 & 0.212 & 0.551 & $\mathrm{NS}$ \\
\hline
\end{tabular}

JBF- Jackfruit Bulb Flour, JSF- Jackfruit Seed Flour, CF- Cassava Flour

Table 2. Evaluation of nutritional parameters of amaranthus incorporated raw functional jackfruit pasta

\begin{tabular}{|c|c|c|c|c|c|c|c|}
\hline Treatments & $\begin{array}{l}\text { Starch } \\
(\%)\end{array}$ & $\begin{array}{l}\text { Total } \\
\text { sugar (\%) }\end{array}$ & $\begin{array}{l}\text { Reducing } \\
\text { sugar (\%) }\end{array}$ & $\begin{array}{l}\text { Protein } \\
\text { (\%) }\end{array}$ & $\begin{array}{l}\text { Carotenoids } \\
\left(\mu \mathrm{g} 100 \mathrm{~g}^{-1}\right)\end{array}$ & $\begin{array}{l}\text { Crude } \\
\text { fibre (\%) }\end{array}$ & $\begin{array}{l}\text { Antioxidant } \\
\text { activity (\%) }\end{array}$ \\
\hline $\begin{array}{l}\mathrm{F}_{1}[\mathrm{JBF}(20 \%) \\
+\mathrm{JSF}(20 \%)+ \\
\mathrm{CF}(25 \%)]\end{array}$ & 67.32 & 6.58 & 4.77 & 12.68 & 6.12 & 2.57 & 90.47 \\
\hline $\begin{array}{l}\mathrm{F}_{2}[\mathrm{JBF}(25 \%) \\
+\mathrm{JSF}(25 \%)+ \\
\mathrm{CF}(15 \%)]\end{array}$ & 68.06 & 6.86 & 4.91 & 12.45 & 6.64 & 3.56 & 90.64 \\
\hline $\begin{array}{l}\mathrm{F}_{3}[\mathrm{JBF}(10 \%)+ \\
\mathrm{JSF}(30 \%)+\mathrm{CF} \\
(25 \%)]\end{array}$ & 69.38 & 5.71 & 3.97 & 13.86 & 5.73 & 1.83 & 90.81 \\
\hline $\begin{array}{l}\mathrm{F}_{4}\left[\mathrm{~F}_{1}+5 \%\right. \\
\text { Amaranthus }]\end{array}$ & 65.06 & 6.88 & 4.95 & 13.41 & 6.25 & 4.07 & 93.94 \\
\hline $\begin{array}{l}\mathrm{F}_{5}\left[\mathrm{~F}_{1}+10 \%\right. \\
\text { Amaranthus }]\end{array}$ & 64.53 & 7.07 & 5.05 & 13.58 & 6.34 & 4.66 & 94.35 \\
\hline $\begin{array}{l}\mathrm{F}_{6}\left[\mathrm{~F}_{2}+5 \%\right. \\
\text { Amaranthus }]\end{array}$ & 66.19 & 7.18 & 5.16 & 13.54 & 6.54 & 4.53 & 94.74 \\
\hline $\begin{array}{l}\mathrm{F}_{7}\left[\mathrm{~F}_{2}+10 \%\right. \\
\text { Amaranthus }]\end{array}$ & 66.66 & 7.28 & 5.24 & 13.69 & 6.83 & 4.82 & 94.85 \\
\hline $\begin{array}{l}\mathrm{F}_{8}\left[\mathrm{~F}_{3}+5 \%\right. \\
\text { Amaranthus }]\end{array}$ & 68.51 & 6.19 & 4.77 & 14.97 & 5.87 & 2.40 & 94.95 \\
\hline $\begin{array}{l}\mathrm{F}_{9}\left[\mathrm{~F}_{3}+10 \%\right. \\
\text { Amaranthus }]\end{array}$ & 68.71 & 6.22 & 4.83 & 15.06 & 5.92 & 2.89 & 95.21 \\
\hline $\mathrm{CD}$ & NS & NS & 1.157 & NS & NS & 1.469 & 3.41 \\
\hline
\end{tabular}


Cooking quality, nutritional composition and consumer acceptance

Table 3. Evaluation of nutritional parameters of cooked amaranthus incorporated functional jackfruit pasta

\begin{tabular}{|c|c|c|c|c|c|c|c|}
\hline Treatments & $\begin{array}{l}\text { Starch } \\
(\%)\end{array}$ & $\begin{array}{l}\text { Total } \\
\text { sugar }(\%)\end{array}$ & $\begin{array}{l}\text { Reducing } \\
\text { sugar }(\%)\end{array}$ & $\begin{array}{l}\text { Protein } \\
\text { (\%) }\end{array}$ & $\begin{array}{l}\text { Carotenoid } \\
\mathrm{s}\left(\mu \mathrm{g} 100 \mathrm{~g}^{-1}\right)\end{array}$ & $\begin{array}{l}\text { Crude } \\
\text { fibre (\%) }\end{array}$ & $\begin{array}{l}\text { Antioxida } \\
\text { nt activity } \\
\text { (\%) }\end{array}$ \\
\hline $\begin{array}{l}\mathrm{F}_{1}[\mathrm{JBF}(20 \%)+ \\
\mathrm{JSF}(20 \%)+\mathrm{CF} \\
(25 \%)]\end{array}$ & 45.61 & 4.52 & 1.55 & 5.87 & 1.57 & 0.12 & 61.35 \\
\hline $\begin{array}{l}\mathrm{F}_{2}[\mathrm{JBF}(25 \%)+ \\
\mathrm{JSF}(25 \%)+\mathrm{CF} \\
(15 \%)]\end{array}$ & 47.73 & 4.78 & 1.69 & 6.12 & 1.74 & 0.20 & 64.37 \\
\hline $\begin{array}{l}\mathrm{F}_{3}[\mathrm{JBF}(10 \%)+ \\
\mathrm{JSF}(30 \%)+\mathrm{CF} \\
(25 \%)]\end{array}$ & 53.28 & 3.75 & 1.15 & 6.56 & 1.34 & 0.10 & 68.56 \\
\hline $\begin{array}{l}\mathrm{F}_{4} \quad\left[\mathrm{~F}_{1}+5 \%\right. \\
\text { Amaranthus }]\end{array}$ & 42.72 & 4.56 & 1.69 & 6.43 & 2.00 & 2.31 & 66.58 \\
\hline $\begin{array}{l}\mathrm{F}_{5} \quad\left[\mathrm{~F}_{1}+10 \%\right. \\
\text { Amaranthus }]\end{array}$ & 42.95 & 4.79 & 1.73 & 6.54 & 2.14 & 2.49 & 67.98 \\
\hline $\begin{array}{l}\mathrm{F}_{6}\left[\mathrm{~F}_{2}+5 \%\right. \\
\text { Amaranthus }]\end{array}$ & 45.21 & 4.86 & 1.85 & 7.26 & 2.07 & 2.54 & 69.33 \\
\hline $\begin{array}{l}\mathrm{F}_{7} \quad\left[\mathrm{~F}_{2}+10 \%\right. \\
\text { Amaranthus }]\end{array}$ & 46.05 & 4.94 & 1.96 & 7.31 & 2.29 & 2.80 & 70.23 \\
\hline $\begin{array}{l}\mathrm{F}_{8} \quad\left[\mathrm{~F}_{3}+5 \%\right. \\
\text { Amaranthus }]\end{array}$ & 46.88 & 4.41 & 1.48 & 7.42 & 1.96 & 1.49 & 70.04 \\
\hline $\begin{array}{l}\mathrm{F}_{9} \quad\left[\mathrm{~F}_{3}+10 \%\right. \\
\text { Amaranthus }]\end{array}$ & 46.07 & 4.53 & 1.55 & 7.57 & 2.11 & 2.19 & 71.32 \\
\hline $\mathrm{CD}$ & 7.946 & 0.716 & 0.488 & 0.737 & 0.778 & 0.441 & 3.809 \\
\hline
\end{tabular}

\section{COLOUR}

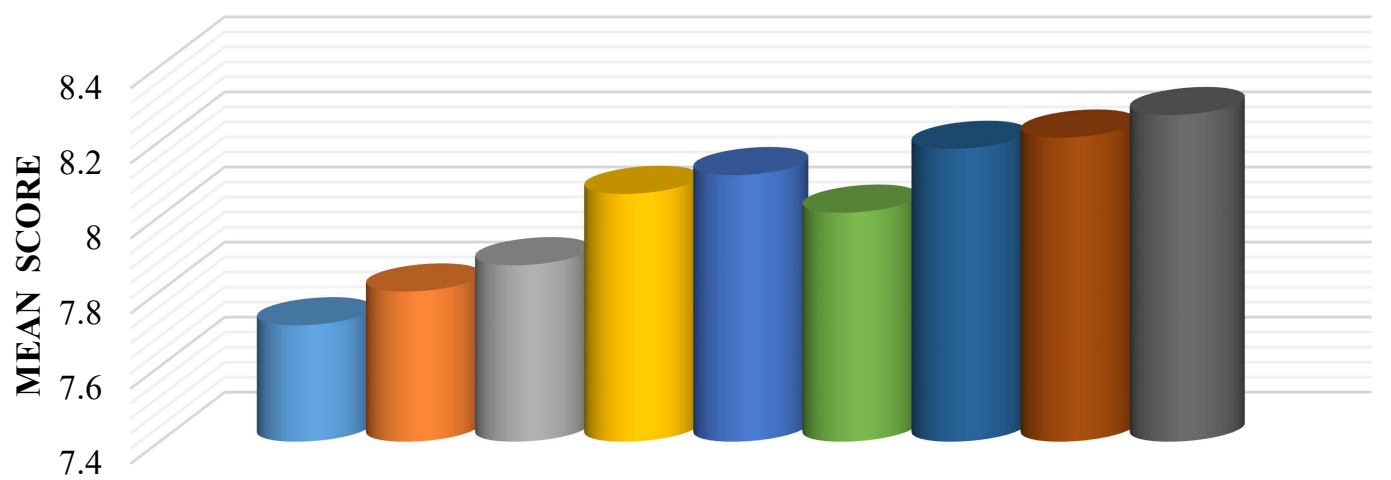

PASTA COMBINATIONS

$\square \mathrm{F} 1 \backsim \mathrm{F} 2 \backsim \mathrm{F} 3 \backsim \mathrm{F} 4 \square \mathrm{F} 5 \square \mathrm{F} 6 \square \mathrm{F} 7 \square \mathrm{F} 8 \square \mathrm{F} 9$

Fig 1.Mean sensory score for colour of amaranthus enriched jackfruit pasta 


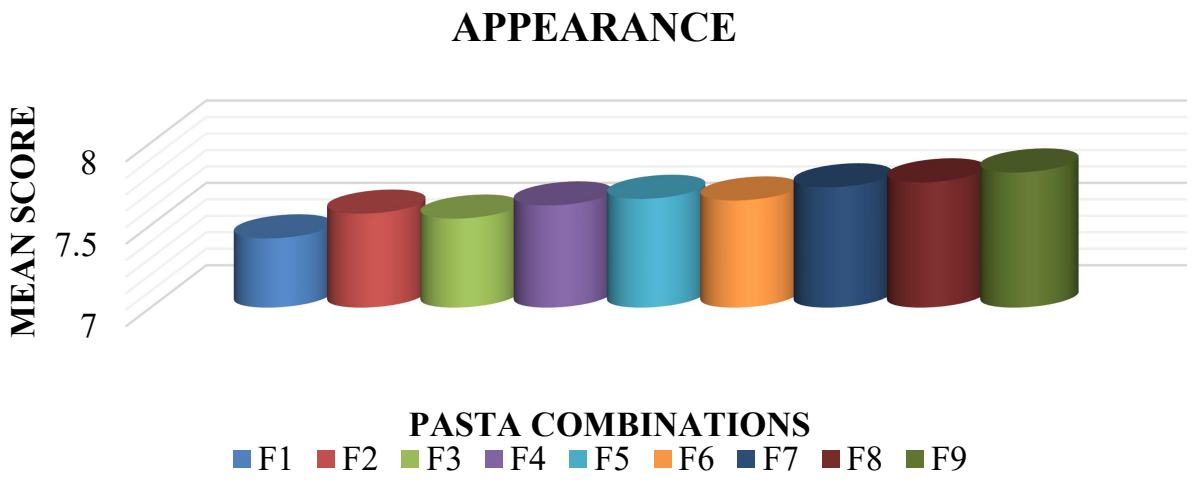

Fig 2.Mean sensory score for appearance of amaranthus enriched jackfruit pasta.

TASTE

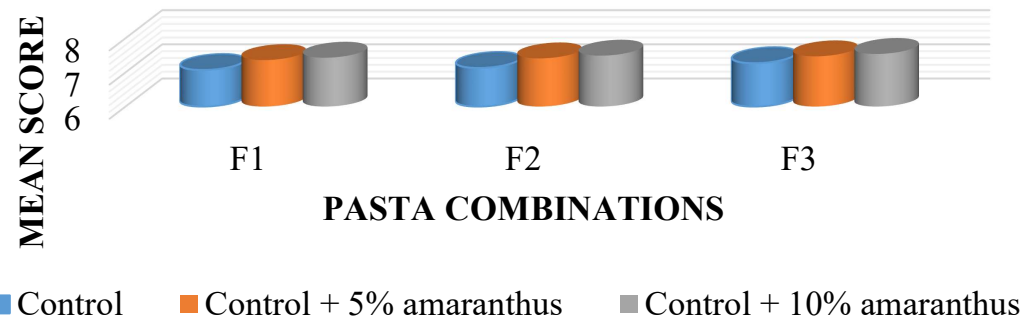

Fig 1.Mean sensory score for taste of amaranthus enriched jackfruit pasta,

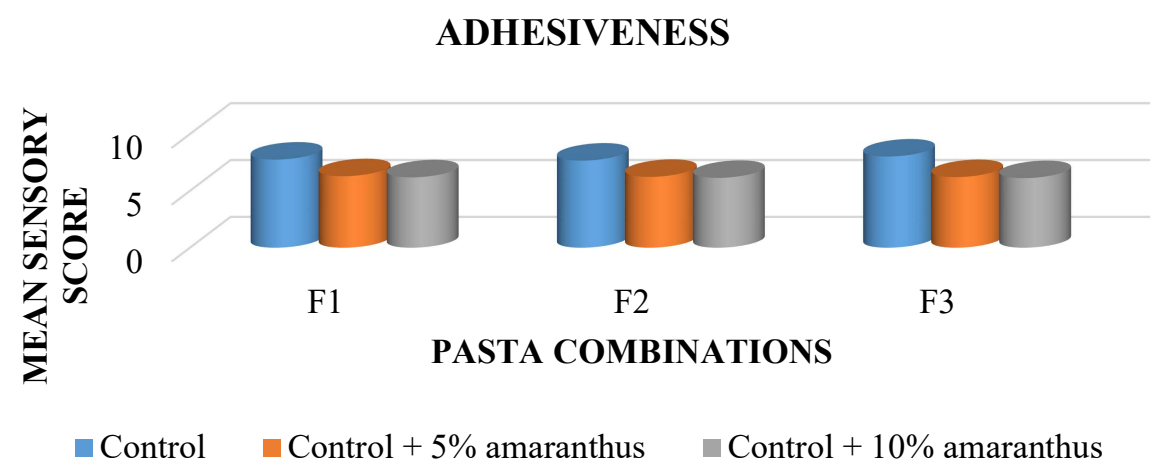

Fig1. Mean sensory score for adhesiveness of amaranthus enriched jackfruit pasta.

Cooking quality characteristics

Cooking quality of jackfruit pasta were analyzed based on the parameters; cooking loss $(\%)$, water absorption $\left(\mathrm{g} \mathrm{g}^{-1}\right)$, swelling index (\%) and cooking time (minutes) and are depicted in Table 1. Cooking loss of developed amaranthus enriched jackfruit pasta ranged from $18.89 \%$ to $6.84 \%$. On comparing the treatments, $\mathrm{F}_{4}-$ Jackfruit bulb flour $(20 \%)+$ Jackfruit seed flour $(20 \%)+$ cassava flour
$(25 \%)+5 \%$ amaranthus, showed the lowest cooking loss of $6.84 \%$ and the highest cooking loss $(18.89 \%)$ was observed for the treatment $\mathrm{F}_{3}[\mathrm{JBF}$ $(10 \%)+\mathrm{JSF}(30 \%)+\mathrm{CF}(25 \%)]$. Cooking loss of jackfruit pasta decreased with incorporation of amaranthus puree in the pasta dough. Similar result was reported by Rekha et al., (2013) that cooking loss of semolina pasta decreased (7.1 to $8.4 \mathrm{~g} \mathrm{~kg}^{-1}$ ) with the addition of vegetable purees like carrot, 
tomato, beetroot and amaranthus. Increase in cooking loss with increase in concentration of amaranth leaf in pasta dough was observed by Cardinas-Hernandez et al. (2016). Pasta enriched with tomato peel showed a slight increase cooking loss ranging from 7.6 to $7.76 \%$ as compared to the control wheat pasta (Padalino et al., 2017). Water absorption of jackfruit pasta ranged from $1.03 \mathrm{~g} \mathrm{~g}^{-1}$ to $1.49 \mathrm{~g} \mathrm{~g}^{-1}$ and the treatment combination with $10 \%$ jackfruit bulb flour, $30 \%$ jackfruit seed flour, $25 \%$ cassava flour and $10 \%$ amaranthus $\left(\mathrm{F}_{9}\right)$ showed the highest water absorption of $1.49 \mathrm{~g} \mathrm{~g}^{-1}$ and the lowest water absorption of $1.03 \mathrm{~g} \mathrm{~g}^{-1}$ was observed for the treatment with $20 \%$ jackfruit bulb flour, $20 \%$ jackfruit seed flour, $25 \%$ cassava flour and $5 \%$ amaranthus $\left(\mathrm{F}_{4}\right)$. Significant difference in water absorption was noticed with jackfruit pasta combinations $\mathrm{F}_{3}$ and $\mathrm{F}_{9}$ with the addition of $10 \%$ amaranthus in pasta formulation. Pasta enriched with carrot leaf meal showed an increase in water absorption with increase in leaf meal concentration in pasta (Boroski et al., 2011). Decrease in water absorption $(131 \%)$ of spaghetti enriched with yellow pepper flour compared to the control spaghetti (141\%) was observed by (Padalino et al., 2013). Sun-Waterhouse et al. (2013), explained that the amount of water absorbed by pasta is determined by the openness in the gluten structure of pasta and increase in elderberry juice concentrate in the wheat pasta led to increase in water absorption of the developed pasta. Swelling index of jackfruit pasta ranged from $1.06 \%$ to $2.58 \%$ and developed pasta with $10 \%$ jackfruit bulb flour, $30 \%$ jackfruit seed flour and $25 \%$ cassava flour $\left(\mathrm{F}_{3}\right)$ recorded the highest swelling index of $2.58 \%$. The lowest swelling index of $1.06 \%$ was noticed for the treatment with $20 \%$ jackfruit bulb flour, 20\% jackfruit seed flour, 25\% cassava flour and 5\% amaranthus. From the study it was observed that with the incorporation of 5\% amaranthus puree, swelling index decreased and it again increased when the concentration of amaranthus increased. Incorporating vegetable purees in pasta decreased the swelling index of developed pasta and it ranged from 1.24 to $1.53 \%$ was reported by Rekha et al. (2013). Padalino et al. (2017) stated that enriched pasta with tomato peel decreased swelling index which might be due to the increase in fibre content in pasta which led to decreased swelling of starch and thereby decreasing the swelling index of pasta.
Cooking time for amaranthus enriched jackfruit pasta ranged from $5.23 \mathrm{~min}$ to $6.22 \mathrm{~min}$ and amaranthus enrichment resulted in lower cooking time even though no statistically significant difference was observed. Pasta enriched with vegetables exhibit a lesser cooking time due to the quicker reconstitution of pasta matrix by the fine vegetable matter (Rekha et al., 2013). Padalino et al. (2017) reported decrease in cooking time with the increase in concentration of tomato peel in pasta and it ranged from 9 to $9.3 \mathrm{~min}$ as compared to $10.2 \mathrm{~min}$ for control spaghetti.

\section{Nutritional parameters}

Starch content of raw jackfruit pasta ranged from $64.53 \%$ to $69.38 \%$ and the treatment combinations did not show significant difference statistically (Table 2). The starch content of all the developed pasta decreased on cooking and it ranged from $45.61 \%$ to $53.28 \%$ with the highest for $\mathrm{F}_{3}-$ jackfruit bulb flour $(10 \%)+$ jackfruit seed flour $(30 \%)+$ cassava flour $(25 \%)]$ and the amaranthus incorporation marginally reduced the starch content with its corresponding jackfruit combinations without significant difference statistically. A decrease in starch content with addition of broccoli leaves was observed by da Silva (2013). Total sugar content of developed raw pasta (uncooked) ranged from $5.71 \%$ to $7.28 \%$ without significant difference among the combinations and the cooked pasta $\mathrm{F}_{7}$ [F2+10\% Amaranthus] recorded the highest starch content of $4.95 \%$. Cardinas-Hernandez et al. (2016), observed a decrease in carbohydrate content with the addition of amaranthus leaf flour in pasta ranging from 72.74 to $65.85 \%$ compared to the control pasta $(75.88 \%)$. Reducing sugar content of uncooked amaranthus enriched jackfruit pasta ranged from $3.97 \%$ to $5.24 \%$ which decreased on cooking and it ranged from $1.15 \%$ to $1.96 \%$. Protein content of raw pasta ranged from $12.45 \%$ to $15.06 \%$ and it decreased on cooking and ranged from $5.87 \%$ to $7.57 \%$ and the highest was for the combination of $10 \%$ jackfruit bulb flour, $30 \%$ jackfruit seed flour, 25\% cassava flour and 10\% amaranthus $\left(\mathrm{F}_{9}\right)$. Rekha et al. (2013) stated that there was no difference in the protein content of pasta enriched with different vegetable purees like carrot, beetroot, tomato and amaranthus. According to Cardinas-Hernandez et al. (2016) the protein content of the pasta enriched with amaranth flour and amaranth leaves were higher as compared to 
the semolina pasta. Carotenoid content of developed pasta varied from $5.73 \mu \mathrm{g} 100 \mathrm{~g}^{-1}$ to 6.83 $\mu \mathrm{g} 100 \mathrm{~g}^{-1}$ in uncooked pasta and amaranthus addition increased the carotenoid content marginally and it ranged from $1.34100 \mathrm{~g}^{-1}$ to

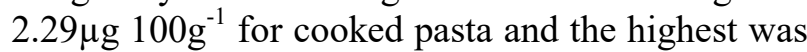
recorded for the combination with $25 \%$ jackfruit bulb flour, $25 \%$ jackfruit seed flour, $15 \%$ cassava flour and $10 \%$ amaranthus $\left(\mathrm{F}_{7}\right)$. Rekha et al. (2013) reported an increase in carotenoid content with addition of vegetable in pasta making. For raw pasta, fibre content varied with the combinations and ranged from $1.83 \%$ to $4.82 \%$ and enrichment with amaranthus increased the fibre content of the developed pasta. On cooking, fibre content decreased in all the combinations where as the percentage decrease was less for amaranthus incorporated pasta. Fibre content of the pasta incorporated with amaranth flour and amaranth leaves (Cardinas-Hernandez et al., 2016) and tomato peel enriched spaghetti (Padalino et al., 2017) were reported as higher than conventional pasta. Antioxidant activity in terms of radical scavenging power (DPPH assay) ranged from $90.47 \%$ to $95.21 \%$ for raw pasta and addition of amaranthus increased the antioxidant activity. For cooked enriched pasta it ranged from from $61.35 \%$ to $71.32 \%$ and the highest was reported for the treatment combination with $10 \%$ jackfruit bulb flour, $30 \%$ jackfruit seed flour, $25 \%$ cassava flour and $10 \%$ amaranthus $\left(\mathrm{F}_{9}\right)$ and all combinations with amaranthus recorded increased antioxidant activity.

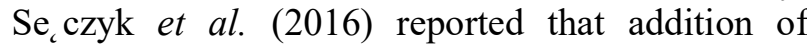
parsley leaves in wheat pasta increased the antioxidant potential of the pasta and Armellini et al. (2018) reported increased activity with saffron enrichment.

\section{Sensory qualities}

Cooked jackfruit pasta was analyzed for various sensory attributes viz., appearance, taste, colour, flavour, elasticity, adhesiveness, overall acceptability and Kruskal Wallis test confirmed difference between the treatment combinations for appearance, taste, colour and overall acceptability (Fig. 1 to Fig. 4). All the amaranthus enriched jackfruit pasta recorded acceptabile sensory scores and among the treatment combinations, the highest mean score for appearance (7.82), colour (8.27), taste (7.54), flavour (7.89), elasticity (8.60), overall acceptability (8.96) and the lowest adhesiveness
(6.12) was recorded for the treatment combination jackfruit bulb flour $(10 \%)+$ jackfruit seed flour $(30 \%)+$ cassava flour $(25 \%)+10 \%$ amaranthus.

\section{Conclusion}

In the present study red amaranthus paste was added at 5\% and $10 \%$ level to the jackfruit pasta dough which contains different proportions of jackfruit bulb flour, jackfruit seed flour and cassava flour replacing a portion of refined flour for the development of healthy functional jackfruit pasta enriched with amaranthus. The study revealed that incorporation of red amarnathus to jackfruit pasta combinations influenced the cooking quality characters and significantly reduced the cooking loss. Water absorption as well as swelling index also varied with percentage of jackfruit bulb, seed and cassava flour and incorporation of amaranthus. Addition of red amaranthus puree marginally reduced the cooking time. The amaranthus enriched jackfruit pasta recorded higher protein, fibre, and carotenoids with higher antioxidant activity and improved nutritional qualities of jackfruit pasta. The natural colour of red amaranthus influenced the pasta colour and recorded the highest sensory attributes. Thus it may be concluded that addition of red amaranthus significantly improved the nutritional and sensory qualities of jackfruit pasta which can be used for the development of healthy nutritious pasta. More work on other vegetables can also be done for the development of nutritious pasta.

\section{Acknowledgement}

The authors are thankful to Kerala Agricultural University for financial assistance and Central Tuber Crop Research Institute for extending the facilities for the research work.

Reference

\section{References}

Amit, K. T. and Ambarish, V. 2010. Production of jackwine A wine from ripe jackfruit. Pharmbit., 22(2): 154-156.

Armellini, R., Peinado, I., Pittia, P., Scampicchio, M., Heredia, A. and Andres, A. 2018. Effect of saffron (Crocus sativus L.) enrichment on antioxidant and sensorial properties of wheat flour pasta. Food Chem., 254: 55-63.

Arung, E.T., Shimizu, K. and Kondo, R. 2007. Structureactivity relationship of prenyl-substituted polyphenols from 


\section{Cooking quality, nutritional composition and consumer acceptance}

Artocarpus heterophyllus as inhibitors of melanin biosynthesis in cultured melanoma cells. Chem. Biodivers. 4(9): 2166-2171.

Boroski, M., de Aguiar, A.C., Boeing, J.S., Rotta, E.M., Wibby, C. L., Bonafé, E. G., de Souza, N. E., and Visentainer, J. V. 2011. Enhancement of pasta antioxidant activity with oregano and carrot leaf. Food Chem.,125(2): 696-700.

Bradford, M.M. 1976. A rapid and sensitive method for the quantitation of microgram quantities of protein utilizing the principle of protein-dye binding. Anal. Biochem.,72(1-2): 248-254.

Cardinas - Hernandez, A., Beta, T., Pina, G. L., Tostado, E. C., Barrera, J. O. N. and Mendoza, S. 2016. Improved functional properties of pasta: Enrichment with amaranth seed flour and dried amaranth leaves. J. Cereal Sci., 72: 84-90.

Chandrika, U.G., Jansz, E.R. and Warnasuriya, N. D. 2005. Analysis of carotenoids in ripe jackfruit (Artocarpus heterophyllus) kernel and study of their bioconversion in rats. J. Sci. Food Agric., 85(2): 186-190.

Cleary, L. and Brennan, C. 2006. The influence of a $(1 \rightarrow 3)$ $(1 \rightarrow 4)-\beta$-glucan rich fraction from barley on the physicochemical properties and in vitro reducing sugars release of durum wheat pasta. Int. J. Food Sci. Technol., 41: 910-918.

Da Silva, V.E.M. 2013. Pasta highly enriched with vegetables:from microstructure to sensory and nutritional aspects. $\mathrm{PhD}$ Thesis, Wagenigen University, wageningen, The Netherlands $17 \mathrm{p}$.

Debbouz, A. and Doetkott, C. 1996. Effect of process variables on spaghetti quality. Cereal Chem.,73(6): 672-676.

Gull, A., Prasad, K. and Kumar, P. 2015. Effect of millet flours and carrot pomace on cooking qualities, colour and texture of developed pasta. Food Sci. Technol., 63: 470-474.

Meena, G.S., Dewan, A., Upadhyay, N., Barapatre, R., Kumar, N., Singh, A. K. and Rana, J. S. 2019. Fuzzy analysis of sensory attributes of gluten free pasta prepared from brown rice, amaranth, flaxseed flours and whey protein concentrates. J. Food Sci., 2(1): 22-37.

Ojure, M.A. and Quadri, J.A. 2012. Quality evaluation of noodles produced from unripe plantain flour using xanthan gum. Int. J. Recent Res. Appl. Stud., 13(3): 740-752.
Padalino, L., Conte, A., Lecce, L., Likyova, D., Sicari, V., Pellicanò, T.M., Poiana, M. and del Nobile, M.A. 2017. Functional pasta with tomato by-product as a source of antioxidant compounds and dietary fibre. Czech $\boldsymbol{J}$. Food Sci., 35: 48-56.

Padalino, L., Mastromatteo, M., Lecce, L., Cozzolino, F. and del Nobile, M.A. 2013. Manufacture and characterization of gluten-free spaghetti enriched with vegetable flour. $\boldsymbol{J}$. Cereal Sci., 57(3): 333-342.

Padmaja, G., Menon, R., Krishnan, J.G. and Sajeev, M.S. 2015. Pasta and Noodles from Tuber Crops as Novel Health Foods. ICAR- Central Tuber Crops Research Institute, Sreekariyam, Thiruvanathapuram, 204p.

Ranasinghe, R. A. S.N., Maduwanthi, S.D.T. and Marapana, R. A.U.J. 2019. Nutritional and health benefits of jackfruit (Artocarpus heterophyllus Lam.): A review. Int. J. Food Sci., 1: 25-37.

Ranganna, S. 1986. Handbook of Analysis and Quality Control for Fruit and Vegetable Products. Tata McGraw-Hill Education, 145p.

Rekha, M.N., Chauhan, A.S., Prabhasankar, P., Ramteke, R.S. and Rao, G.V. 2013. Influence of vegetable purees on quality attributes of pastas made from bread wheat ( $T$. aestivum). CyTA-J. Food, 11(2): 142-149.

Sadasivam, S. and Manikkam, A. 1992. Biochemical Methods of Agricultural Sciences. Wiley eastern Ltd, New Delhi, $8 \mathrm{p}$.

Saini, R.K., Nile, S.H. and Park, S.W. 2015. Carotenoids from fruits and vegetables: Chemistry, analysis, occurrence, bioavailability and biological activities. Food Res. Int. 76: 735-750.

Se czyk, L., S'wieca, M., Gawlik-Dziki, U., Luty, M. and Czyz, J. 2015. Effect of fortification with parsley (Petroselinum crispum Mill.) leaves on the nutraceutical and nutritional quality of wheat pasta. Food Chem., 190: 419-428.

Shamrez, A., Shukla, R.N. and Mishra, A. 2013. Study on drying and quality characteristics of tray and microwave dried guava slices. Int. J. Sci. Eng. Technol., 3(4): 23484098 .

Sharma, O.P. and Bhat, T.K. 2009. DPPH antioxidant assay revisited. Food Chem., 113: 1202-1205.

Sun-Waterhouse, D., Jin, D. and Geoffrey, I. N. 2013. Effect of adding elderberry concentrate on the quality attributes, polyphenol contents and antioxidant activity of three fibre enriched pastas. Food Res. Int., 54: 781-789. 